Sufitrayati, Fanny Nailufar: Keputusan Nasabah dalam Memilih Bank Syariah

\title{
FAKTOR-FAKTOR YANG MEMPENGARUHI KEPUTUSAN NASABAH DALAM MEMILIH BANK SYARI'AH DI KOTA BANDA ACEH
}

\author{
Sufitrayati \\ Jurusan Akuntansi, Fakultas Ekonomi, Universitas Serambi Mekkah \\ sufitrayati@serambimekkah.ac.id \\ Fanny Nailufar \\ Jurusan Manajemen, Fakultas Ekonomi, Universitas Serambi Mekkah \\ fannynaulufar@serambimekkah.ac.id
}

\begin{abstract}
This study aims to determine the analysis of factors that influence customer decisions in choosing a Syari'ah Bank in Banda Aceh City partially or simultaneously. This study uses 100 customers as samples. The results showed that cultural factors, social factors, personal factors and psychological factors have a significant effect on customer decisions in choosing a Sharia Bank in Banda Aceh City, as evidenced by the results of the research showing the percentage of $81.6 \%$ and the remaining $18.4 \%$ influenced by other factors beyond the variables studied. Based on the results of multiple linear regression analysis, it can be seen that of the four variables studied, it turns out that the psychological factor variable (X4) has the most dominant influence on the decision of Sharia Bank customers in Banda Aceh, with a coefficient of 0.828 , then followed by the cultural factor (X1) with a coefficient value of 0.662 , followed by a social factor variable (X2) with a coefficient of 0.549 and followed by a personal factor variable $\left(X_{3}\right)$ with a coefficient of 0.110.
\end{abstract}

Keywords: Cultural Factors, Social Factors, Personal Factors, Psychological Factors of Customer Decisions

\section{ABSTRAK}

Penelitian ini bertujuan untuk mengetahui analisis faktor-faktor yang mempengaruhi keputusan nasabah dalam memilih Bank Syari'ah di Kota Banda Aceh secara parsial maupun secara simultan. Penelitian ini menggunakan 100 orang nasabah sebagai sampel. Hasil penelitian menunjukkan bahwa faktor budaya, faktor sosial, faktor pribadi dan faktor psikologis berpengaruh signifikan terhadap keputusan nasabah dalam memilih Bank Syari'ah di Kota Banda Aceh, yang dibuktikan dengan hasil penelitian menunjukkan persentase $81,6 \%$ dan yang sisanya sebesar $18,4 \%$ dipengaruhi oleh faktor lain diluar variabel yang diteliti. Berdasarkan hasil analisis regresi linier berganda dapat diketahui bahwa dari keempat variabel yang diteliti, ternyata variabel faktor psikologis $\left(\mathrm{X}_{4}\right)$ mempunyai pengaruh paling dominan terh- 
Ihtiyath Vol. 2 No. 1 September 2018

adap keputusan nasabah Bank Syari'ah di Kota Banda Aceh, dengan nilai koefisien sebesar 0,828 , kemudian dikuti oleh variabel faktor budya $\left(X_{1}\right)$ dengan nilai koefisien sebesar 0,662, selanjutnya diikuti oleh variabel faktor sosial $\left(X_{2}\right)$ dengan nilai koefisien sebesar 0,549 dan diikuti oleh variabel faktor pribadi $\left(\mathrm{X}_{3}\right)$ dengan nilai koefisien sebesar 0,110.

Kata Kunci: Faktor Budaya, Faktor Sosial, Faktor Pribadi, Faktor Psikologis Keputusan Nasabah

\section{PENDAHULUAN}

Perbankan syari'ah merupakan salah satu instrument yang digunakan untuk menegakkan aturan-aturan ekonomi islam. Perbankan menerima tiga fungsi utama yaitu menerima simpanan uang, meminjamkan uang, dan meneriam jasa pengiriman uang. Didalam sejarah perekonomian kaum muslim, pembiayaan yang dilakukan dengan akad yang sesuai syari'ah telah menjadi bagian dari tradisi umat islam. Praktik-praktik seperti menerima titipan harta, pembiayaan untuk keperluan konsumsi dan untuk keperluan bisnis (investasi), serta melakukan pengiriman uang telah lazin dilakukan. Dengan demikian fungsi-fungsi utama perbankan modern adalah menerima simpanan, menyalurkan dan mentrasfer dana telah menjadi bagian yang tidak terpisahkan dari kehidupan umat islam, bahkan sejak zaman Rasulullah SAW (Muhammad, 2005: 22-27).

Pemerintah sangat mendukung keberadaan perbankan syari'ah, hal ini dapat diketahui dengan di keluarkannya Undang-Undang No.1 Tahun 1992 tentang perbankan pasal 1 ayat 3 yang menetapkan bahwa salah satu bentuk usaha bank adalah menyediakan pembiayaan atau melakukan kegiatan lain berdasarkan prinsip syari'ah, sesuai dengan ketentuan yang ditetapkan oleh Bank Indonesia (BI). Semakin banyak bank-bank yang menggunakan sistem bagi hasil (bank syari'ah) di Indonesia dapat memberikan sebuah solusi bagi umat islam dalam dunia perekonomian. Namun banyak faktor yang mempengeruhi nasabah memilih bank syriah, diantaranya faktor sosial, faktor pribadi, faktor psikologi dan faktor budaya.( Nurain, 2007).

Faktor budaya merupakan salah satu faktor penentu keputusan konsumsi. Wibowo dan Widodo (2005), mengungkapkan bahwa alasan nasabah penyimpan dana membuka rekening tentunya bukan pada bunga yang tinggi, tetapi pada metode bagi hasil sesuai dengan syariah dan tersedianya fasilitas tabungan Biaya Naik Haji. Selanjutnya disamping fak- 
Sufitrayati, Fanny Nailufar: Keputusan Nasabah dalam Memilih Bank Syariah

tor budaya yang mempengaruhi keputusan nasabah juga ditentukan oleh faktor pribadi.

Faktor pribadi merupakan cara mengumpulkan dan mengelompokkan kekonsistenan reaksi seorang individu terhadap situasi yang sedang terjadi (Lamb, 2001:221). Perilaku seseorang dalam membeli sesuatu juga dipengaruhi oleh faktor-faktor kepribadian dari konsumen yang bersangkutan. Faktor pribadi menggabungkan antara tatanan psikologis dan pengaruh lingkungan. Termasuk watak, dasar seseorang, terutama karakteristik dominan mereka. Meskipun kepribadian adalah salah satu konsep yang berguna dalam mempelajari perilaku konsumen, beberapa pemasar percaya bahwa kepribadian mempengaruhi jenis-jenis dan merek-merek produk yang dibeli.

Menurut Engel (1994:285): “Kebutuhan yang diaktifkan akhirnya menjadi diekspresikan dalam perilaku dan pembelian dan konsumsi dalam bentuk dua jenis manfaat yaitu: pertama manfaat utilitarian dan kedua manfaat hedonik/pengalaman". Kenudian Engel menambahkan dalam motif pembelian produk dengan mempertimbangkan dua manfaat yaitu: "Manfaat utilitarian merupakan atribut produk fungsional yang obyektif. Manfaat hedonik, sebaliknya mencakup respon emosional, kesenangan panca indera, mimpi dan pertimbangan-pertimbangan estetis"

Perilaku seseorang dipengaruhi oleh faktor sosial, meliputi kelompok refensi, pembuat keputusan keluarga, peran dan status. (Blackwell, Best dan Motherbaugh, 2007), menjelaskan tiga bentuk pengaruh kelompok referensi: information, utilitarity, dan value expressive. Enam bentuk pengaruh keluarga meliputi: influencer, gatekeeper, decider, buyer, user, disposer. Morrisan (2010:132) menjelaskan kedudukan seseorang dalam kelompok dapat ditentukan berdasarkan peranan dan situs. Setiap peran membawa status yang mencerminkan dan mengkomunikasikan peran mereka serta status actual atau status yang diinginkan dalam masyarakat. Dalam hal ini penulis melakukan penelitian tentang Apakah faktor-faktor yang mempengaruhi keputusan nasabah dalam memilih Bank Syari'ah di Kota Banda Aceh.

\section{Bank Syari'ah}

Menurut Muhammad (2005:13) bank islam atau disebut bank syari'ah, adalah bank yang beroperasi dengan tidak mengandalkan pada bunga. Bank syari'ah juga dapat diartikan sebagai lembaga keuangan/perbankan yang operasional dan produknya dikembang- 
kan berdasarkan Al-Qur'an dan Hadist Nabi SAW. Perwataatmadja dan Tanjung (2007:7576). Bank syari'ah dirancang untuk terbinanya kebersamaan dalam menanggung resiko usaha dan berbagai hasil usaha antara pemilik dana (shahibul mal) yang menyimpan uangnya di bank. Bank selaku pengelola dana (mudharib). Dan di sisi lain bank selaku pemilik dana dengan masyarakat yang membutuhkan dana baik yang berstatus pemakai dana maupun pengelola usaha (mudharib).

Pada sisi penghimpunan dana masyarakat (funding), pemilik dana (shahibul mal) berhak atas bagi hasil dari usaha bank sesuai dengan porsi yang telah disepakati bersama. Bagi hasil yang diterima pemilik dana (shahibul mal) akan naik turun secara wajar sesuai dengan keberhasilan usaha bank dalam mengelola dana yang dipercayakan kepadanya. Tidak ada biaya yang perlu digeserkan karena bagi hasil bukan konsep biaya.

Ada tiga jenis produk utama penghimpunan dana masyarakat, yaitu:

a) Giro wadiah (hanya pada bank umum syariah).

b) Tabugan wadiah atau mudharabah.

c) Deposito mudharabah.

Lain halnya pada pendapatan mark-up, pilihan terletak pada apakah ingin sekaligus untung besar pertransaksi tetapi menjadi mahal dan tidak laku, atau keuntungan pertransaksi kecil tetapi dengan volume yang besar karena murah dan laku keras.Pendapatan bank dapat dioptimalkan dengan mengambil kebijakan keuntungan kecil pertransaksi untuk memperbanyak jumlah transaksi yang dibiayai.

\section{Jenis-Jenis Pembiayaan Utama}

Menurut Muhammad (2002:91), “manajemen bank syariah menyalurkan dana pada nasabah yang secara garis besar produk pembiayaan terbagi dalam beberapa kategori yang dibedakan berdasarkan tujuan penggunaannya, yaitu :

a. Pembiayaan musyarakah, yaitu pembiayaan sebagai kebutuhan modal pada suatu usaha untuk jangka waktu terbatas sesuai kesepakatan. Hasil usaha bersih dibagi antara bank sebagai penyandang dana (shahibul mal) dengan pengelola usaha (mudharib) sesuai dengan kesepakatan. Umumnya porsi bagi hasil ditetapkan sesuai dengan presentase kontribusi masing-masing. Pada akhir jangka waktu pembiayaan, dana pembiayaan dikembalikan kepada bank. Pada pembiayaan musy- 
Sufitrayati, Fanny Nailufar: Keputusan Nasabah dalam Memilih Bank Syariah

arakah bank boleh ikut serta dalam manajemen proyek yang dibiayai.

b. Pembiayaan mudharabah, yaitu pembiayaan seluruh kebutuhan modal pada suatu usaha untuk jangka waktu terbatas sesuai kesepakatan. Hasil usaha bersih dibagi antara bank sebagai penyandang dana (shahibul mal) dengan pengelola usaha (mudharib) sesuai kesepakatan. Umumnya porsi bagi hasil ditetapkan bagi mudharabah lebih besar dari pada shahibul mal. Pada akhir jangka waktu pembiayaan, dana pembiayaan dikembalikan kepada bank. Pada pembiyaan mudharabah bank tidak boleh ikut serta dalam manajemen proyek yang dibiayai.

c. Pembiayaan murabaha, yaitu pembiayaan berupa tanlangan dana yang dibutuhkan nasabah untuk membeli suatu barang/jasa dengan kewajiban mengembalikan talangan dana tersebut seluruhnya pada waktu jatuh tempo. Bank memperole mergin keuntungan dari transaksi jual-beli antara bank dengan pemasok dan antara bank dengan nasabah, model pengembalian talangan dana seluruhnya pada waktu jatu tempo biasanya diberikan kepada objek pembiayaan yang tidak segera menghasilkan, seperti untuk kebutuhan traktor petani tidak mungkin dibayar kembali sebelum tanamannya menghasilkan/panen.

d. Pembiayaan salam, yaitu pembiayaan berupa talangan dana yang dibutuhkan nasabah untuk membeli suatu barang/jasa yang sudah wujud tetapi masih harus menunggu waktu penyerahannya, dengan kewajiban mengembalikan talangan dana tersebut secara menyicil atau dibayar sekaligus sampai lunas dalam jangka waktu tertentu sesuai dengan kesepakatan. Bank memperoleh margin keuntungan dari transaksi jual-beli antara bank dengan pemasok dan antara bank dengan nasabah.

e. Pembiayaan istishna, yaitu pembiayaan berupa talangan dana yang dibutuhkan nasabah untuk membeli suatu barang /jasa yang belum wujud dan harus sesuai spesifikasi yang telah ditetapkan dengan kewajiban mengembalikan talangan dana tersebut secara menyicil atau dibayar sekaligus sampai lunas dalam jangka waktu tertentu sesuai dengan kesepakatan. Bank memperoleh margin keuntungan melalui transakasi jual-beli antara bank dengan pemasok dan antara bank dengan nasabah.

f. Pembiayaan ijarah, yaitu pembiayaan berupa tanlangan dana yang dibutuhkan nasabah untuk membeli suatu barang/jasa dengan kewajiban menyewa barang terse- 
Ihtiyath Vol. 2 No. 1 September 2018

but sampai jangka waktu tertentu sesuai dengan kesepakatan, pada akhir jangka waktu tersebut pemilikan barang dihibahkan kepada nasabah atau dibeli oleh nasabah, bank memperoleh margin keuntungan melalui pembelian dari pemasok dan sewa dari nasabah".

\section{Keputusan Nasabah}

Menurut Kotler (2002:234) mengemukakan bahwa keputusan adalah sebuah proses pendekatan penyelasain masalah yang terdiri dari pengenalan masalah, mencari informasi, beberapa penilaian alternative, membuat keputusan membeli dan perilaku setelah membeli yang dilalui konsumen. Pengertian keputusan menurut Drumond (2007:251) adalah mengidentifikasikan semua pilihan yang mungkin untuk memecahkan persoalan itu dan menilai pilihan-pilihan secara sistematis dan obyektif serta sasaran-sasarannya yang menentukan keuntungan serta kerugianya masing-masing.

Keputusan merupakan bagian atau salah satu elemen penting dari perilaku nasabah disamping kegiatan fisik yang melibatkan nasabah dalam menilai, mendapatkan dan mempergunakan barang-barang serta jasa ekonomis.Perspektif pemecahan masalah mencakup semua jenis perilaku pemenuhan kebutuhan dan jajaran luas dari faktor-faktor yang memotivasikan dan mempengaruhi keputusan nasabah. Tahap-tahap proses keputusan pembelian dapat digambarkan dalam sebuah model seprti terlihat pada gambar 2.1 .

\section{Tahap Proses Membeli}

\begin{tabular}{|c|c|c|c|c|}
\hline $\begin{array}{l}\text { Pengenalan } \\
\text { masalah }\end{array}$ & $\begin{array}{l}\text { Pencarian } \\
\text { informasi }\end{array}$ & $\begin{array}{l}\text { Evaluasi } \\
\text { alternatif }\end{array}$ & $\begin{array}{c}\text { Kepuasan } \\
\text { membeli }\end{array}$ & $\begin{array}{c}\text { Perilaku } \\
\text { pasca } \\
\text { membeli }\end{array}$ \\
\hline
\end{tabular}

\section{Gambar 2.1 Tahap Proses Membeli}

Sumber : Kotler, 2007:235

\section{Budaya}

Budaya dapat didefinisikan sebagai hasil kreativitas manusia dari satu generasi ke generasi berikutnya yang sangat menentukan bentuk perilaku dalam kehiduapannya sebagai anggota masyarakat. Kebudayaan merupakan suatu hal yang kompleks yang meliputi 
Sufitrayati, Fanny Nailufar: Keputusan Nasabah dalam Memilih Bank Syariah

ilmu pengetahuan, kepercayaan, seni, moral, adat, kebiasaan, dan norma-norma yang berlaku pada masyarakat (Mangkunegara, 2005:39).

Flemming Hansen (1972:172-173) dalam Mangkunegara (2005:39-40) yang merupakan bahwa karakteristik budaya adalah : "culture is man-made, is learned, culture is presicriptive, culture is socially shared, culture are similiar but difference, culture is gratifying and persistent, culture is adaptive, culture is organized and integrated". Kebudayaan adalah hasil karya manusia, proses belajar, mempunyai aturan atau berpola, bagian dari masyarakat, menunjukan kesamaan tertentu tetapi pula terdapat variasi-variasinya, pemenuhan kepuasaan dan kemandapan atau ketetapan, penyesuaian, terorganisasi dan terintergrasi secara keseluruhan.

\section{Sosial}

Kelas sosial merupakan salah satu dimensi kebudayaan, seperti yang diungkapkan Kotler dan Keller (2006: 166).Dimensi sosial merupakan salah satu faktor karakteristik konsumen yang berpengaruh terhadap perilaku konsumen. Dengan demikian, kelas sosial seorang konsumen memengaruhi perilaku konsumsinya.

Wells dan Prensky (1996: 150) menyatakan bahwa kelas sosial mengacu pada posisi tertentu dalam struktur sosial dan ekonomi suatu masyarakat, yang didasarkan pada kriteria pendapatan, pendidikan, dan pekerjaan.Konsep ini menunjukkan bahwa ada tiga dimensi kelas sosial, yaitu tingkat pendapatan, tingkat pendidikan, dan tingkat pekerjaan.

\section{Pribadi}

Perilaku seseorang dalam membeli sesuatu juga dipengaruhi oleh faktor-faktor kepribadian dari konsumen yang bersangkutan.Faktor pribadi menggabungkan antara tatanan psikologis dan pengaruh lingkungan.Termasuk watak, dasar seseorang, terutama karakteristik dominan mereka. Meskipun kepribadian adalah salah satu konsep yang berguna dalam mempelajari perilakukonsumen, beberapa pemasar percaya bahwa kepribadian mempengaruhi jenis-jeni dan merek-merek produk yang dibeli

Keputusan membeli juga dipengaruhi oleh karakteristik pribadi, karakteristik tersebut meliputi : usia dan tahap dalam siklus hidup, pekerjaan, keadaan ekonomi, kepribadian dan konsep diri, serta nilai dan gaya hidup pembeli. Mangkunegara, (2005), Kepribadian 
Ihtiyath Vol. 2 No. 1 September 2018

dapat didefinisikan sebagai suatu bentuk dari sifat-sifat yang ada pada diri individu yang sangat menentukan perilakunya. Kepribadian konsumen sangat ditentukan oleh faktor internal dirinya (motif, IQ, emosi, cara berpikir, persepsi) dan faktor eksternal dirinya (lingkungan fisik, keluarga, masyarakat, sekolah, lingkungan alam).

\section{Psikologis}

Pilihan pembelian seseorang dipengaruhi oleh empat faktor psikologis utama, yaitu motivasi, persepsi,pengetahuan, keyakinan dan sikap. Semakin tinggi motivasi, persepsi, pengetahuan, keyakinan dan sikap seseorangterhadap suatu produk, maka semakin tinggi keputusan konsumen untuk melakukan pembelian Frederecca dan Chairy (2010:141)

Menurut Kotler (2005:197) persepsi adalah proses yang digunakan oleh konsumen untuk memilih, mengorganisasi, dan menginterprestasikan masukan-masukan informasi guna menciptakan gambaran dunia yang memiliki arti. Menurut machfoedz persepsi adalah proses memilih, penyusunan, dan penafsiran informasi untuk mendapatkan arti. Persepsi tidak hanya bergantung pada rangsangan fisik tetapi juga pada rangsangan yang berhubungan dengan lingkungan sekitar dan keadaan individu yang bersangkutan.

\section{Penelitian Terdahulu}

Nany Roedjinandari (2006) dengan judul pengaruh faktor-faktor perilaku konsumen terhadap keputusan pembelian makanan khas jawa pada rumah makan Inggil Malang. Penelitian ini diuji dengan analisis deskriktif dari hasil penelitian menunjukan bahwa adanya hubungan yang signifikan dari variable kelompok referensi sebagai variable dengan faktor tempat, pribadi, sosial dan psikologi terhadap keputusan pembelian dirumah makan inggil malang. Berdasarkan analisis regresi dapat diketahui model penelitian menunjukan model yang sudah fit bias ditunjukan uji model dengan nilai $F$ yang signifikan pada alpha 0,005 .

Nuraini (2006), didalam penelitian yang berjudul “ Analisis Faktor-faktor yang Mempengaruhi Keputusan Nasabah Menggunakan Jasa Bank Syariah pada PT. BPRS PUDUARTA INSANI". Menyimpulkan bahwa faktor yang paling mempengaruhi keputusan nasabah menggunakan jasa bank syariah pada PT. BPRS PUDUARTA INSANI adalah " faktor ag- 
Sufitrayati, Fanny Nailufar: Keputusan Nasabah dalam Memilih Bank Syariah

ama, fasilitas pelayanan, pribadi dan psikologi”. Didalam penelitian tersebut, teknik analisis yang digunakan adalah analisis regresi linear berganda pada tingkat signifikasinya $=1 \%$

Penelitian yang dilakukan oleh Pratama (2007) dengan judul Analisa Faktor-Faktor Yang Mempengaruhi Keputusan Nasabah Untuk Menggunakan Jasa Bank Syariah.Hasil penelitian menunjukkan bahwa faktor yang paling dominan mempengaruhi keputusana nasabah untuk menggunakan jasa bank syariah adalah faktor promosi, budaya, dan sosial.Dalam penelitian ini metode yang digunakan adalah uji validitas, reabilitas, analisis deskriptif, dan analisis regresi linier berganda.

\section{Kerangka Pemikiran}

Kerangka berfikir adalah model konseptual tentang bagaimana teori berhubungan dengan berbagai faktor yang telah diidentifikasi sebagai masalah yang penting (Uma Sekaran dalam Sugiyono, 2009:88). Kerangka pemikiran dalam penilitian ini fokus pada pengaruh faktor budaya, sosial, pribadi dan psikologi terhadap keputusan nasabah dalam memilih bank syri'ah. Berdasarkan landasan teori di atas, maka diperlukan sebuah analisa mengenai bagaimana pengaruh faktor budaya, sosial, pribadi dan psikologi terhadap keputusan nasabah dalam memilih bank syari'ah. Maka kerangka pemikiran dalam penilitian ini menggunakan analisis regresi berganda, dapat gambar 2.2.
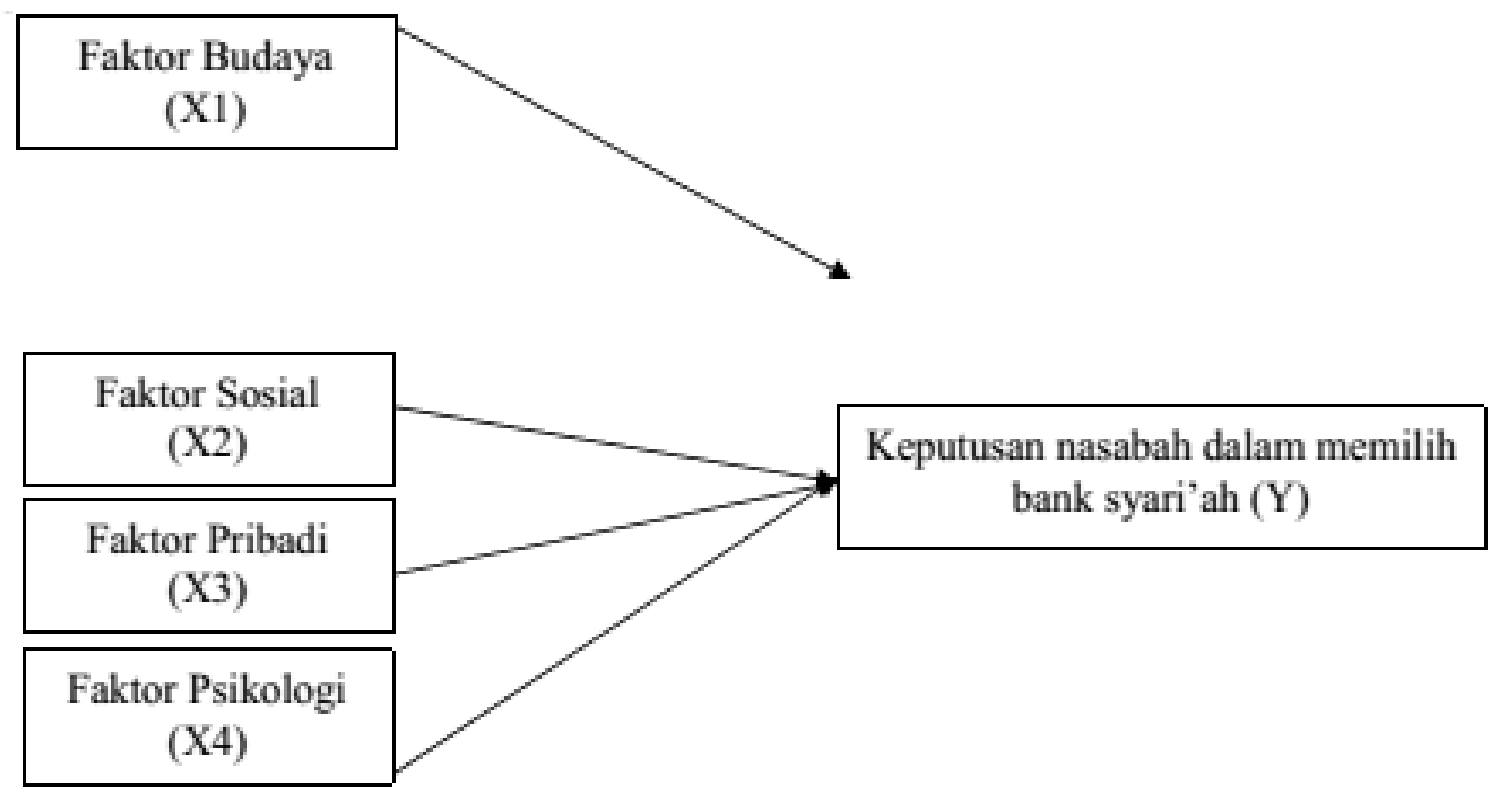

\section{Gambar 2.2 Kerangka Pemikiran}


Ihtiyath Vol. 2 No. 1 September 2018

\section{Hipotesis Penelitian}

Berdasarkan teori dan penilitian sebelumnya maka hipotesis dalam penilitian ini adalah:

$\mathrm{H}_{1}$ : Diduga faktor budaya, sosial, pribadi, psikologi secara bersama-sama berpengaruh terhadap keputusan nasabah memilih Bank Sayri'ah di Kota Banda Aceh.

$\mathrm{H}_{2}$ : Diduga faktor budaya secara individual terdapat pengaruh terhadap keputusan nasabah memilih Bank Sayri'ah di Kota Banda Aceh.

$\mathrm{H}_{3}$ : Diduga faktor sosial secara individual terdapat pengaruh terhadap keputusan nasabah memilih Bank Sayri'ah di Kota Banda Aceh.

$\mathrm{H}_{4}$ : Diduga faktor pribadi secara individual terdapat pengaruh terhadap keputusan nasabah memilih Bank Sayri'ah di Kota Banda Aceh.

$\mathrm{H}_{5}$ : Diduga faktor psikologi secara individual terdapat pengaruh terhadap keputusan nasabah memilih Bank Sayri'ah di Kota Banda Aceh.

\section{METODE PENELITIAN}

\section{Lokasi dan Objek}

Studi ini dilakukan terhadap nasabah yang memilih bank syariah di Kota Banda Aceh sebagai tempat menabung, karena Kota Banda Aceh adalah pusat kepemerintahan sekaligus Ibu Kota Provinsi Nanggro Aceh Darusslam, Banda Aceh juga menjadi pusat perekonomian, politik, sosial, dan budaya.

\section{Ruang Lingkup Penelitian}

Didalam ruang lingkup penelitian adanya penekanan batas lokasi, waktu dan variabel-variabel yang dibahas. Hal ini sangat diperlukan agar penelitian tidak keluar dari wilayah yang ditelitinya dan akan sangat berguna bagi para pemula (Hamid, 2007:28) Penelitian ini menggunakan metode analisis kulitatif dan analisis kuantitatif. Sebelum analisis deskriptif ini dilakukan, penulis terlebih dahulu melakukan analisis validitas dan reabilitas untuk mengukur tingkat kevalidan dan keandalan kuesioner. Dalam penelitian ini ruang lingkupnya dibatasi pada budaya, sosial, pribadi, dan psikologi terhadap keputusan nasabah. 
Sufitrayati, Fanny Nailufar: Keputusan Nasabah dalam Memilih Bank Syariah

Lokasi dan objek yang akan diteliti adalah masyarakat dikota Banda Aceh yang menggunakan Bank Syari'ah.

\section{Populasi dan Sampel}

Populasi merupakan jumlah keseluruhan yang mencangkup semua anggota yang akan diteliti (Istijanto, 2009:113). Populasi dalam penelitian ini adalah masyarakat Kota Banda Aceh yang menggunakan bank syari'ah. Sampel adalah bagian dari jumlah dan karakteristik yang dimiliki oleh populasi (Sugiyono, 2008:91).

Pengambilan sampel dalam penelitian ini yaitu menggunakan metode convenience sampling, yaitu istilah umum yang mencangkup variasi luasnya prosedu pemilihan responden. Convenience sampling berarti unit sampling yang ditarik mudah dihubungi, tidak menyusahkan, mudah untuk mengukur, dan bersifat koperatif (Hamid, 2007:30).

Penentuan sampel penelitian ini menggunkanrumus Slovin(Ridwan dan Engkos, 2008:49).

$$
n=\frac{N}{1+N e^{2}}
$$

\section{Keterangan:}

$\mathrm{n}=$ jumlah sampel

$\mathrm{N}=$ jumlah populasi

$1=$ kostanta

$E=$ Persen Kelonggaran ketidak telitian karena kesalahan pengambilan sampel yang masih dapat ditolerir.

Berdasarkan sensus penduduk tahun 2014 di kota Banda Aceh jumlah penduduk adalah 248.784 jiwa. Maka penentuan sampelnya sebagai berikut :

Dari hasil perhitungan diatas dibulatkan menjadi 100 sampel yang merupakan nasabah pengguna jasa perbankan syariah. Responden yang digunakan dalam penelitian ini adalah masyarakat Kota Banda Aceh. 
Ihtiyath Vol. 2 No. 1 September 2018

Adapun sampel pada penelitian ini dibebankan pada setiap kecamatan di kota Banda Aceh dapat di lihat pada tabel 3.1

Tabel 3.1

\section{Data Sampel}

\begin{tabular}{|c|l|c|}
\hline No & \multicolumn{1}{|c|}{ Kecamatan } & Jumlah \\
\hline 1 & Kecamatan Baiturrahman & 11 \\
\hline 2 & Kecamatan Banda Raya & 11 \\
\hline 3 & Kecamatan Jaya Baru & 11 \\
\hline 4 & Kecamatan Kuta Alam & 11 \\
\hline 5 & Kecamatan Kuta Raja & 11 \\
\hline 6 & Kecamatan Lung Bata & 12 \\
\hline 7 & Kecamatan Meuraksa & 11 \\
\hline 8 & Kecamatan Syiah Kuala & 11 \\
\hline 9 & Kecamatan Ule Kareng & 11 \\
\hline & & $\mathbf{1 0 0}$ \\
\hline
\end{tabular}

\section{Teknik Pengumpulan Data}

Tehnik pengumpulan data dalam penelitian ini adalah Data primer, yaitu diperoleh peneliti dengan pengisisan kuesioner yang diisi oleh responden yaitu para nasabah pengguna jasa bank syariah. Husein Umar ( 2002), Kuesioner berisi pertanyaan mengenai data responden dan pertanyaan yang bersifat tertutup dengan skala likert. Data sekunder merupakan data-data yang diperoleh dari berbagai literatur baik dalam bentuk buku, majalah, koran, internet, jurnal dan lain-lain. Dalam penelitian sekunder ini merupakan data pendukung.

\section{Operasional Variabel}

Operasional Variabel dalam penelitian ini adalah, dapat dilihat pada Tabel 3.1 sebagai berikut;

Tabel 3.1

\section{Definisi dan Operasionalisasi Variabel}

\begin{tabular}{|c|c|c|c|c|}
\hline Variabel & Definisi & Indikator & $\begin{array}{c}\text { Item Per- } \\
\text { tanyaan }\end{array}$ & Skala \\
\hline
\end{tabular}


Sufitrayati, Fanny Nailufar: Keputusan Nasabah dalam Memilih Bank Syariah

\begin{tabular}{|c|c|c|c|c|}
\hline $\begin{array}{l}\text { Budaya } \\
\text { (X1) }\end{array}$ & $\begin{array}{l}\text { Budaya adalah kebiasan } \\
\text { suatu masyarakat dalam } \\
\text { menanggapi sesuatu yang } \\
\text { dianggap memiliki nilai dan } \\
\text { kebiasaan, yang bisa dim- } \\
\text { ulai dari mereka meneri- } \\
\text { ma informasi, posisi sosial } \\
\text { mereka dalam masyarakat, } \\
\text { dan pengetahuan mereka } \\
\text { tentang apa yang mereka } \\
\text { rasakan. Purimahua (2005 } \\
\text { :545) }\end{array}$ & $\begin{array}{l}\text { a. Sub-budaya } \\
\text { b. Kelas sosial }\end{array}$ & 5 & Iterval \\
\hline $\begin{array}{l}\text { Sosial } \\
\left(X_{2}\right)\end{array}$ & $\begin{array}{l}\text { Sosial adalah sekelompok } \\
\text { orang yang mampu mem- } \\
\text { pengaruhi perilaku indivi- } \\
\text { du dalam melakukan suatu } \\
\text { tindakan berdasarkan ke- } \\
\text { biasaan, faktor sosial ini ter- } \\
\text { diri dari kelompok referensi, } \\
\text { keluarga peranan dan sta- } \\
\text { tus. Purimahua ( } 2005: 545) \\
\end{array}$ & $\begin{array}{l}\text { a. Kelompok } \\
\text { acuan } \\
\text { b. Keluarga } \\
\text { c. Peran dan } \\
\text { status }\end{array}$ & 5 & Iterval \\
\hline $\begin{array}{l}\text { Pribadi } \\
\text { (X3) }\end{array}$ & $\begin{array}{l}\text { Pribadi adalah pola ke- } \\
\text { biasaan seseorang yang } \\
\text { dipengaruhi oleh lingkun- } \\
\text { gan terdekat dalam me- } \\
\text { nentukan pilihan, kemu- } \\
\text { dian diekspresikan dalam } \\
\text { suatu tindakan. Purimahua } \\
(2005: 545)\end{array}$ & $\begin{array}{l}\text { a. Umur dan } \\
\text { tahap siklus } \\
\text { hidup } \\
\text { b. Pekerjaan } \\
\text { c. Keadaan } \\
\text { ekonomi } \\
\text { d. Gaya hidup } \\
\text { e. Kepribadian } \\
\text { dan konsep } \\
\text { diri }\end{array}$ & 5 & Iterval \\
\hline
\end{tabular}


Ihtiyath Vol. 2 No. 1 September 2018

\begin{tabular}{|c|c|c|c|c|}
\hline $\begin{array}{l}\text { Psikolo- } \\
\text { gi (X4) }\end{array}$ & $\begin{array}{l}\text { Psikologis adalah dorongan } \\
\text { dari diri seseorang yang } \\
\text { mempengaruhi pemilihan } \\
\text { sesuatu berdasarkan atas } \\
\text { keluwasan terhadap produk } \\
\text { yang digunakan, keinginan } \\
\text { yang lebih besar dan kemu- } \\
\text { dahan penggunaan produk } \\
\text { tersebut dibandingkan den- } \\
\text { gan yang lain. Purimahua } \\
(2005: 545)\end{array}$ & $\begin{array}{l}\text { a. Motivasi } \\
\text { b. Persepsi } \\
\text { c. Pembelaja- } \\
\text { ran } \\
\text { d. Keper- } \\
\text { cayaan diri } \\
\text { dan sikap }\end{array}$ & 5 & Iterval \\
\hline $\begin{array}{l}\text { Kepu- } \\
\text { tusan } \\
\text { Nasa- } \\
\text { bah } \\
(\mathrm{Y})\end{array}$ & $\begin{array}{l}\text { keputusan adalah sebuah } \\
\text { proses pendekatan penye- } \\
\text { lasain masalah yang terdiri } \\
\text { dari pengenalan masalah, } \\
\text { mencari informasi, beber- } \\
\text { apa penilaian alternative, } \\
\text { membuat keputusan mem- } \\
\text { beli dan perilaku setelah } \\
\text { membeli yang dilalui kon- } \\
\text { sumen. Kotler (2002:234) }\end{array}$ & $\begin{array}{l}\text { Wajar jika na- } \\
\text { sabah memilih } \\
\text { bank syriah }\end{array}$ & 5 & Iterval \\
\hline
\end{tabular}

\section{Alat Analisis Data}

Ridwan, Engkos Achmad Kuncoro (2008), Analisis ini digunakan sebagai alat ukur untuk mengetahui seberapa besar tingkat pengaruh antara variabel independent $(X)$ dengan variabel dependen $(Y)$. Metode ini juga bisa digunakan sebagai ramalan sehingga dapat diperkirakan antara baik atau buruknya suatu variabel $X$ terhadap naik turunnya suatu tingkat variabel $Y$ begitu juga sebaliknya. Untuk menghitung regresi linear berganda digunakan rumus sebagai berikut:

$$
Y=a+\beta_{1} X_{1}+\beta_{2} X_{2}+\beta_{3} X_{3}+\beta_{4} X_{4}+e
$$

Dimana:

$$
\begin{array}{ll}
\mathrm{Y} & =\text { Keputusan Nasabah dalam Memilih Bank Syariah } \\
\mathrm{X}_{1} & =\text { Kebudayaan } \\
\mathrm{X}_{2} & =\text { Sosial } \\
\mathrm{X}_{3} & =\text { Pribadi } \\
\mathrm{X}_{4} & =\text { Psikologis } \\
\mathrm{a} & =\text { Intersip atau Konstanta }
\end{array}
$$




$$
\begin{array}{ll}
\beta_{1,2,3,4} & =\text { Koefisien Regresi } \\
\mathrm{e} & =\text { Standar Error }
\end{array}
$$

\section{PEMBAHASAN}

\section{Hasil Uji Asumsi Klasik}

\section{Pengujian Normalitas}

Uji normalitas data digunakan untuk melakukan pengujian data observasi apakah data tersebut berdistribusi normal atau tidak (Sarwono, 2012:96). Uji normalitas dilakukan dengan menggunakan pendekatan kolmogorv sminorv dan normalitas dilakukan dengan uji Shapiro-Wilk menggunakan taraf signifikansi 0,05. Jika sig > 0,05 maka data berdistribusi norma. Hasil pengolahan data menghasilkan normal normal probability plot dapat dilihat pada Gambar 4.1.

\section{Gambar 4.1}

\section{Normal Probability Plot Hasil Pengujian Normalitas Data}
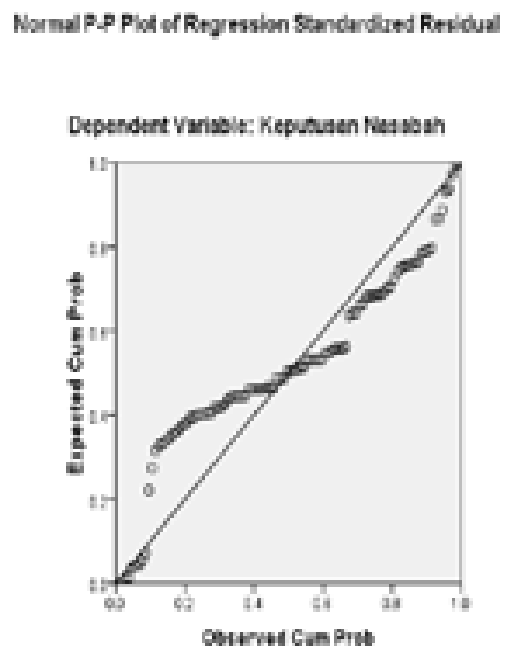

Berdasarkan Gambar 4.1 diatas dapat dilihat bahwa grafik normal probability plot mengetuhi garis diagonalnya sehingga dapat diartikan bahwa data normal probability plot yang digunakan dalam penelitian ini terdistribusi secara normal. 
Ihtiyath Vol. 2 No. 1 September 2018

\section{Pengujian Heteroskedastisitas}

Pada pengujian heteroskedastisitas akan digunakan uji Gleyser, dengan cara mengorelasikan nilai absolute residualnya dengan masing-masing variabel independen. Jika hasil nilai probabilitasnya memiliki nilai signifikansi > 0,05, maka model tidak mengalami heteroskedastisitas (Wibowo, 2012:93). Hasil pengolahan data menunjukkan grafik scatterplot seperti terlihat pada Gambar 4.2.

\section{Gambar 4.2}

\section{Grafik Scatterplot Hasil Pengujian Heteroskesdastisitas}

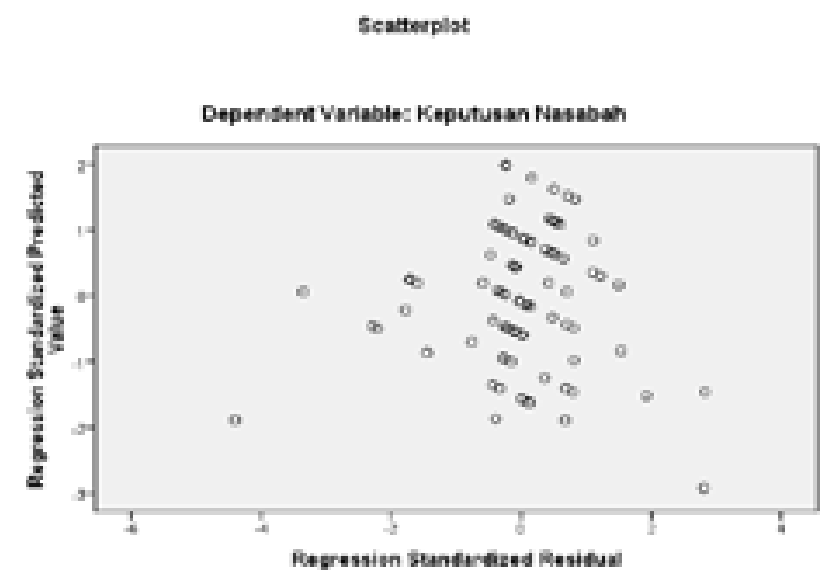

Berdasarkan Gambar 4.2 diatas memperlihatkan bahwa grafik scatterplot menunjukkan bahwa titik-titik menyebar di atas dan dibawah angka o pada sumbu $Y$ dan tidak memiliki pola tertentu, maka dapat diartikan tidak terjadi gejala heteroskedastisitas.

\section{Regresi Linier Berganda}

Analisis dilakukan sesuai dengan peralatan analisis data yang digunakan untuk mengetahui hubungan fungsional antara variabel yang diteliti dalam penelitian ini, mengenai faktor-faktor yang mempengaruhi keputusan nasabah Bank Syari'ah di Kota Banda Aceh. Setelah data dikumpulkan, maka lewat bantuan SPSS 22. untuk diformulasikan ke regresi linier berganda, seperti terlihat pada Tabel 4.1. 


\section{Tabel 4.1}

\section{Hasil Perhitungan Regresi}

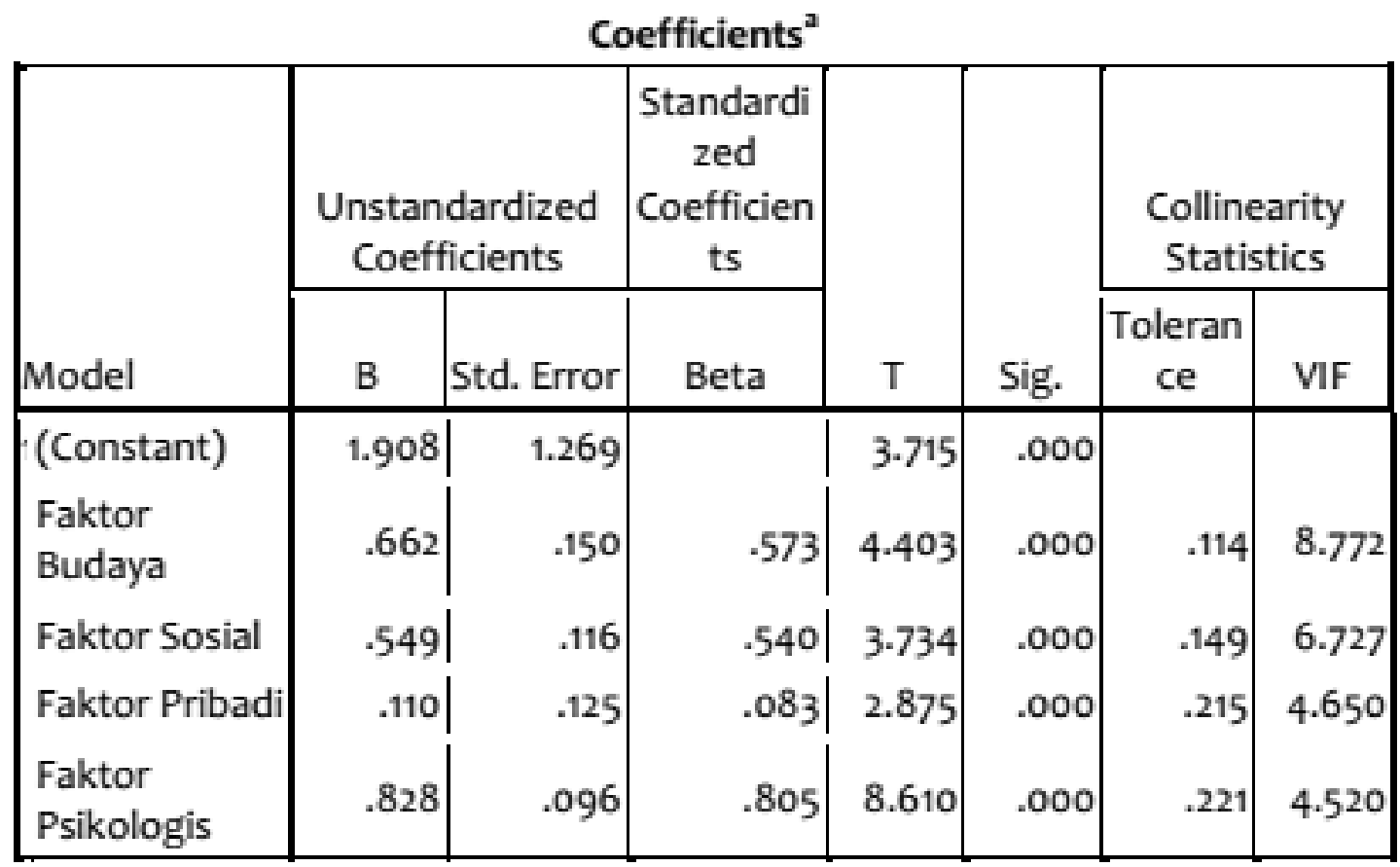

\section{a. Dependent Variable:}

\section{Keputusan Nasabah}

Sumber: Data Primer (Diolah), 2015.

Berdasarkan Tabel 4.2 maka persamaan regresi yang memperlihatkan keputusan nasabah Bank Syari'ah di Kota Banda Aceh sebagai fungsi dari faktor budaya, faktor sosial, faktor pribadi dan faktor psikologis dapat diformulasikan dalam persamaan sebagai berikut ini:

$$
Y=1,908+0,662 X_{1}+0,549 X_{2}+0,110 X_{3}+0,828 X_{4}+e
$$

Untuk lebih jelasnya mengenai hasil uji F sebagai tolak ukur pengujian hipotesis dapat dilihat Tabel 4.2. 
Ihtiyath Vol. 2 No. 1 September 2018

Tabel 4.2

Hasil Uji Simultan

\begin{tabular}{|c|c|c|c|c|c|}
\hline \multicolumn{6}{|c|}{ ANOVA $^{\mathrm{b}}$} \\
\hline Model & $\begin{array}{l}\text { Sum of } \\
\text { Squares }\end{array}$ & Df & Mean Square & $\mathrm{F}$ & Sig. \\
\hline $\begin{array}{ll}1 & \text { Regression } \\
\text { Residual } \\
\text { Total }\end{array}$ & $\begin{array}{r}410.927 \\
92.463 \\
503.390 \\
\end{array}$ & \begin{tabular}{r|}
4 \\
95 \\
99 \\
\end{tabular} & $\begin{array}{r}102.732 \\
.973\end{array}$ & 105.551 & $.000^{2}$ \\
\hline
\end{tabular}

a. Predictors: (Constant), Faktor Psikologis, Faktor Pribadi, Faktor Sosial, Faktor Budaya

b. Dependent Variable: Keputusan Nasabah

\section{Koefisien Korelasi dan Determinasi}

Untuk melihat hubungan dan pengaruh dari variabel pengaruh faktor budaya, faktor sosial, faktor pribadi dan faktor psikologis terhadap keputusan nasabah Bank Syari'ah di Kota Banda Aceh, berdasarkan korelasi dan determinasi dapat dilihat pada Tabel 4.3

\section{Tabel $4 \cdot 3$}

\section{Korelasi (R) dan Determinasi ( $\left.R^{2}\right)$}

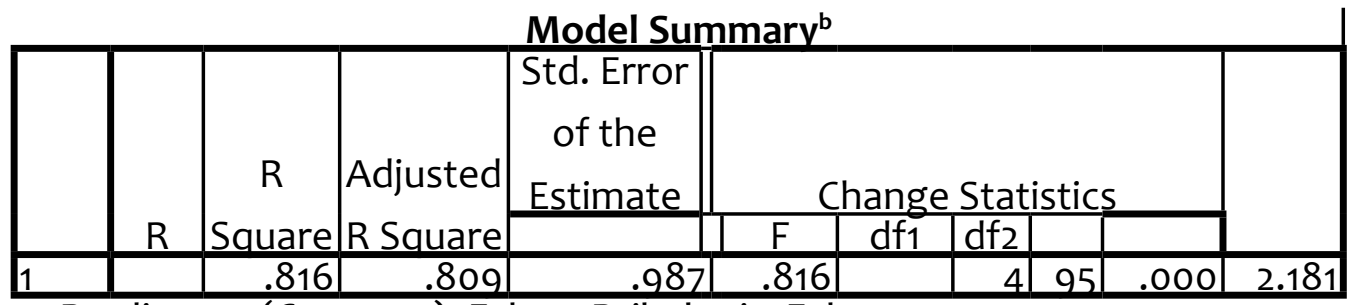

a. Predictors: (Constant), Faktor Psikologis, Faktor

Pribadi, Faktor Sosial, Faktor Budaya

b. Dependent Variable: Keputusan

Nasabah

Sumber: Data Primer (Diolah), 2015.

Berdasarkan hasil regresi linier berganda bahwa besarnya hasil koefesien regresi, korelasi dan determinasi untuk variabel faktor budaya, faktor sosial, faktor pribadi dan faktor psikologis secara simultan berpengaruh signifikan terhadap keputusan nasabah Bank Syari'ah di Kota Banda.

Hasil pengujian statistik menunjukkan nilai $\mathrm{F}_{\text {hitung }}>\mathrm{F}_{\text {tabel }}(105,551>2,467)$ dapat diartikan se- 
Sufitrayati, Fanny Nailufar: Keputusan Nasabah dalam Memilih Bank Syariah

cara simultan keempat variabel independen faktor budaya $\left(\mathrm{X}_{1}\right)$, faktor sosial $\left(\mathrm{X}_{2}\right)$, faktor pribadi $\left(\mathrm{X}_{3}\right)$ dan faktor psikologis $\left(\mathrm{X}_{4}\right)$ berpengaruh signifikan terhadap keputusan nasabah Bank Syari'ah di Kota Banda Aceh, sehingga hipotesis dalam penelitian ini Ha diterima.

Nilai konstanta ( $\alpha$ ) sebesar 1,908 artinya jika faktor budaya, faktor sosial, faktor pribadi dan faktor psikologis dianggap konstan, maka besarnya keputusan nasabah Bank Syari'ah di Kota Banda Aceh adalah sebesar 1,908 pada satuan skala likert cukup memuaskan.

Hasil koefisien regresi factor budaya $\left(\mathrm{X}_{1}\right)$ sebesar 0,662, artinya bahwa setiap $100 \%$ perubahan dalam variabel factor budaya, maka secara relatif akan mempengaruhi keputusan nasabah Bank Syari'ah di Kota Banda Aceh sebesar 66,2\% dengan demikian semakin tinggi pengaruh faktor budaya akan semakin mempengaruhi keputusan nasabah Bank Syari'ah di Kota Banda Aceh.

Hasil faktor sosial $\left(\mathrm{X}_{2}\right)$ sebesar 0,549 artinya bahwa setiap 100\% perubahan dalam variabel faktor sosial, maka secara relatif akan mempengaruhi keputusan nasabah Bank Syari'ah di Kota Banda Aceh sebesar 54,9\% dengan demikian semakin tinggi pengaruh faktor sosial akan semakin mempengaruhi keputusan nasabah Bank Syari'ah di Kota Banda Aceh.

Hasil oefisien regresi faktor pribadi $\left(X_{3}\right)$ sebesar 0,110 artinya bahwa setiap 100\% perubahan dalam variabel faktor pribadi, maka secara relatif akan mempengaruhi keputusan nasabah Bank Syari'ah di Kota Banda Aceh sebesar 11,0\% dengan demikian semakin tinggi pengaruh faktor pribadi akan semakin mempengaruhi keputusan nasabah Bank Syari'ah di Kota Banda Aceh.

Hasil oefisien regresi faktor psikologis $\left(\mathrm{X}_{4}\right)$ sebesar 0,828 , artinya bahwa setiap $100 \%$ perubahan dalam variabel faktor psikologis, maka secara relatif akan mempengaruhi keputusan nasabah Bank Syari'ah di Kota Banda Aceh sebesar 82,8\% dengan demikian semakin tinggi pengaruh faktor psikologis akan semakin mempengaruhi keputusan nasabah Bank Syari'ah di Kota Banda Aceh.

Hasil Koefisien korelasi (R) sebesar 0,904 yang menunjukkan bahwa derajat hubungan (korelasi) antara variabel bebas dengan variabel terikat sebesar 90,4\%, artinya keputusan nasabah Bank Syari'ah di Kota Banda Aceh mempunyai hubungan yang sangat kuat dan 
Ihtiyath Vol. 2 No. 1 September 2018

positif dengan faktor budaya $\left(\mathrm{X}_{1}\right)$, faktor sosial $\left(\mathrm{X}_{2}\right)$, faktor pribadi $\left(\mathrm{X}_{3}\right)$ dan faktor psikol$\operatorname{ogis}\left(\mathrm{X}_{4}\right)$.

Korelasi determinasi $\left(R^{2}\right)$ sebesar 0,816, artinya sebesar 81,6\% perubahan-perubahan dalam variabel terikat (keputusan nasabah) dapat dijelaskan oleh perubahan-perubahan dalam faktor budaya $\left(X_{1}\right)$, faktor sosial $\left(X_{2}\right)$, faktor pribadi $\left(X_{3}\right)$ dan faktor psikologis $\left(X_{4}\right)$. Sedangkan selebihnya yaitu sebesar $18,4 \%$ dijelaskan oleh variabel lain diluar dari pada penelitian ini.

Hasil penelitian ini sejalan dengan penelitian yang dilakukan oleh Nany Roedjinandari (2006) bahwa faktor sosial dan faktor pribadi berpengaruh terhadap keputusan, selanjutnya penelitian Pratama (2007) bahwa pengetahuan tentang faktor budaya dan sosial terhadap keputusan.

\section{KESIMPULAN}

Berdasarkan hasil penelitian dapat disimpulkan beberapa hal sebagai berikut:

1. Faktor budaya, faktor sosial, faktor pribadi dan faktor psikologis secara simultan berpengaruh signifikan terhadap keputusan nasabah Bank Syari'ah di Kota Banda Aceh.

2. Faktor budaya secara parsial berpengaruh signifikan terhadap keputusan nasabah Bank Syari'ah di Kota Banda Aceh sebesr 66,2\%.

3. Faktor sosial secara parsial berpengaruh signifikan terhadap keputusan nasabah Bank Syari'ah di Kota Banda Aceh sebesar 54,9\%.

4. Faktor pribadi secara parsial berpengaruh signifikan terhadap keputusan nasabah Bank Syari'ah di Kota Banda Aceh sebasar 11,0\%.

5. Faktor psikologis secara parsial berpengaruh signifikan terhadap keputusan nasabah Bank Syari'ah di Kota Banda Aceh sebasar 82,8\%.

6. Hasil korelasi determinasi $\left(\mathrm{R}^{2}\right)$ sebesar 0,816 , artinya sebesar $81,6 \%$ perubahan-perubahan dalam variabel terikat (keputusan nasabah) dapat dijelaskan oleh perubahan-perubahan dalam faktor budaya, faktor sosial, faktor pribadi dan faktor psikol- 
Sufitrayati, Fanny Nailufar: Keputusan Nasabah dalam Memilih Bank Syariah

ogis. Sedangkan selebihnya yaitu sebesar 18,4\% dijelaskan oleh variabel lain diluar dari pada penelitian ini.

\section{Saran}

Berdasarkan kesimpulan yang diperoleh dari hasil penelitian, beberapa saran yang diusulkan adalah:

1. Bank Syari'ah harus dapat mempertahankan atau meningkatkan dalam waktu yang sama dalam memotivasi, meningkatkan persepsi, memberikan pembelajaran yang baik dalam memberikan keyakinan dalam mengambil keputusan nasabah dalam memilh Bank Syari'ah di Kota Banda Aceh.

2. Untuk mengukur tingkat keputusan keputusan nasabah Bank Syari'ah di Kota Banda Aceh dapat dengan melihat faktor budaya, faktor sosial, faktor pribadi dan faktor psikologis yang pada akhirnya akan memperbaiki keputusan nasabah dalam memilih Bank Syariah baik individu maupun kelompok.

3. Tetap mempertahankan variabel faktor psikologis merupakan variabel yang paling dominan dalam mempengaruhi keputusan nasbah dalam memelih Bank Syari'ah. Untuk itu pihak perusahaan hendaknya lebih menekankan pada variabel faktor psikologis agar tingkat keputusan nasbah dalam memeilh Bank Syari'ah dapat meningkat setiap tahunnya

4. Variabel faktor pribadi merupakan variabel terpenting yang perlu diperhatikan karena pengaruhnya paling sedikit dibandingkan dengan faktor budaya, faktor sosial dan faktor psikologi karena dengan adanya faktor pribadi yang baik maka keputusan nasabah dalam memilih Bank Syari'ah dapat bertambah setiap harinya.

\section{DAFTAR PUSTAKA}

Drummond, Helga. 2007. “metode penelitian bisnis”, edisi kelima, jilid 1. Erlangga. Jakarta.

Fauzana Ilhami. 2009. "Analisis Pengaruh Pelayanan dan Safe Deposite Box Terhadap Keputusan Nasabah Serta Dampaknya pada Loyalitas Nasabah". FEB UIN. Jakarta.

Hamid, Abdul. 2007. “Panduan Penulisan Skripsi, Cetakan 1. Jakarta : FEIS UIN Pres 
Ihtiyath Vol. 2 No. 1 September 2018

Istijanto, 2009 "Aplikasi Praktis Riset Pemasaran-Cara Praktis Meneliti Konsumen dan Pesaing”, Cetakan Kedua. Gramedia Pustaka Utama. Jakarta.

Kolter Philip, Kevin Lane Keller, 2007 “Manajemen Pemasaran”. Indeks. Jakarta.

Mangkunegara, Anwar Prabu. 2005. Sumber Daya Manusia perusahaan. Remaja Rosdakarya: Bandung.

Muhammad. 2005. Bank Syariah Problem dan Proses Perkembangan di Indonesia. Graha Ilmu. Yogyakarta.

Nuraini. 2011. Analisis faktor-faktor yang mempengaruhi keputusan nasabah menggunakan jasa bank syariah pada PT BPRS Puduarta Insani. Skripsi. USU. Medan.

Purimahua. 2005. "Faktor-Faktor yang Berpengaruh terhadap Perilaku Mahasiswa dalam Memilih Jurusan Ekonomi Pembangunan pada Fakultas Ekonomi Universitas Kristen Maluku di Ambon". Jurnal Keuangan dan Perbankan. Th. IX. No. 2. Mei. Hal. 541 - 551. Universitas Kristen Maluku. Ambon.

Rahmatika, Mufti. 2010. Analisis Faktor-Faktor Ynag Mempengaruhi Pengusaha Kecil dan menengah (UKM). Telaah Dan Riset Akuntansi. Jurnal Vol. 4 No. 2. Jakarta.

Roedjinandari Nany.”Pengaruh Faktor Perilaku Konsumen Terhadap Keputusan Pembelian Makanan Khas Jawa Pada Rumah Makan Inggil Malang"Jurnal Eksekutif,Vol 3 Nomor 3 Desember 2006. Malang.

Sudartik. 2009. "Pengaruh Kualitas Pelayanan dan Periklanan Terhadap Keputusan Nasabah Dalam Menabung pada PT BPR Semarang Margatama Gunadana", Fakultas Ekonomi Universitas Negeri Semarang. Semarang.

Sudin Haron, Norafifah Ahmad and Sandra L. Planisek. 1994. "Bank Patronage Factors of Muslim and Non-Muslim Customers". International Jurnal of Bank Marketing, Vol.12 No.1.

Sugiyono, 2010, "Statistika untuk Penelitian", Cetakan ke-16. Alfabeta. Bandung.

Undang - Undang Nomor 23 Tahun 1999 tantang Bank Indonesia.

Undang-undang Nomor 10 tahun 1998 tentang perubahan undang-undang no.7 tahun 1992.

Wibowo, E. dan Widodo, U.H. 2005, Mengapa Memilih Bank Syariah? .Ghalia Indonesia. Bogor. 